\title{
The role of brain natriuretic peptide in the monitoring of ascites and treatment in chronic liver disease
}

\section{Beyin natriüretik peptidin(BNP) asit moniterizasyonu ve kronik karaciğger hastalığı tedavisindeki rolü}

\author{
Özlem Cakınn ${ }^{1}$ Büllent Yildırım²
}

${ }^{1}$ Internal Medicine Department, Intensive Care Unit, Health Sciences University, Antalya Education and Research Hospital, Antalya, Turkey ${ }^{2}$ Internal Medicine Department, Gastroenterology Clinic, Akdeniz University Faculty of Medicine, Antalya, Turkey

Corresponding author: Özlem Çakın, MD, Internal Medicine Department, Intensive Care Unit, Health Sciences University, Antalya Education and Research Hospital, Antalya, Turkey

E-mail: zlmckndr@gmail.com

Received/Accepted: September 28, 2020 / October 26, 2020

Conflict of interest: There is not a conflict of interest.

\section{SUMMARY}

Objective: The aim of the study was to show the possible relationship between ascites formation and plasma Brain Natriuretic Peptide (BNP) levels, and to determine the importance of that relation for diagnosis and treatment in cirrhosis patients .

Method: Forty-seven cirrhosis patients who had been followed in Akdeniz University Gastroenterology outpatient clinic were enrolled in the study. The proBNP levels and ultrasonographic (USG) ascites levels of the patients had been recorded together with the initial laboratory findings. After a 3-month period, proBNP and ascites levels had been determined in routine controls. Corresponding baseline and control results were evaluated.

Results: Plasma proBNP levels were significantly increased in patients with ascites at baseline and control. The baseline group had a proBNP level of $137.04 \pm 69 \mathrm{pg} / \mathrm{ml}(\mathrm{p}<0.05)$, and the control group $160.78 \pm 76 \mathrm{pg} / \mathrm{ml}(\mathrm{p}<0.05)$. Patients in the baseline cirrhosis group with ascites and control cirrhosis patients with increased and unchanged ascites level showed a significant increase in plasma proBNP levels with $140 \pm 59.3 \mathrm{pg} / \mathrm{ml}$ at baseline and $206.01 \pm 61.91$ $\mathrm{pg} / \mathrm{ml}$ after 3 months ( $\mathrm{p}<0.05$ ). Plasma pro BNP level was observed to decrease in patients with decreased ascites level, however. In the group with increased ascites level, proBNP level was $140.2 \pm 51 \mathrm{pg} /$ $\mathrm{ml}$ at the baseline, and $206.1 \pm 58 \mathrm{pg} / \mathrm{ml}$ after 3 months $(\mathrm{p}<0.05)$. ProBNP was identified to be decreased in the ascites group, however, the change was not statistically significant.

Conclusions: proBNP levels are significantly higher in patients with initial cirrhosis. There is a significant relationship between the amount of ascites fluid and plasma proBNP levels in cirrhosis patients.Although a numerical decrease in the group with decreased ascites was identified, the change was not statistically significant.
Özlem Çakın

Bülent Yıldırım

ORCID IDs of the authors: Ö.Ç. 0000-0002-0907-4095 B.Y. 0000-0001-7793-6139 Keywords: Cirrhosis, proBNP, ascites 
Amaç: Çalışmanın amac1; Siroz hastalarında asit oluşumu ile plazma Beyin Natriüretik Peptit (BNP) miktarı arasında olası ilişkiyi göstermek ve tanı tedavide yerini belirlemektir.

Yöntem: Akdeniz Üniverisitesi Gastroenteroloji polikliniğinde takipli 47 siroz hastası çalışmaya alındı. Hastaların başlangıç labaratuvar bulguları ile birlikte proBNP düzeyleri ve Ultrasonagrofik (USG) asit miktarları kaydedildi. Üç ay sonra kontrole gelen hastalarda yapılan rutin kontrollerdeki proBNP ve asit düzeyleri tespit edildi. Bu süreçteki başlangıç ve kontrol sonuçları değerlendirildi.

Bulgular: Başlangıç ve kontrolde asit sıvısı olan hastalarda plazma proBNP düzeyleri anlamlı şekilde artmıştır. Başlangıç grubu 137,04 $\pm 69 \mathrm{pg} / \mathrm{ml}(\mathrm{p}<0.05)$, kontrol grubunda $160,78 \pm 76 \mathrm{pg} / \mathrm{ml}(\mathrm{p}<0.05)$ olarak bulundu. Asiti olan başlangıç siroz grubundaki hastalar ve kontrolde asit mayisi artmış ve sabit kalmış siroz hastalarında plazma proBNP düzeylerinde anlamlı bir artış gösterdi. Başlangıçta $140 \pm 59.3 \mathrm{pg} / \mathrm{ml}$ ve 3 ay sonra $206.01 \pm 61.91 \mathrm{pg} / \mathrm{ml}$ bulundu $(\mathrm{p}<0.05)$. Asit miktarı artan grupta NT-proBNP düzeyi başlangıçta $140.2 \pm 51 \mathrm{pg} / \mathrm{ml}$; kontrol sırasında ise $206.1 \pm 58 \mathrm{pg} / \mathrm{ml}$ bulunmuştur. $(\mathrm{p}<0.05)$. Asit sıvısı azalan grupta proBNP düşmüștür ama istatistiksel olarak anlamlı değildi.

Sonuç: Başlangıç siroz hastalarında proBNP düzeyleri anlamlı olarak yüksektir. Siroz hastalarında oluşan asit sıvı miktarı ile plazma proBNP düzeyleri arasında anlamlı bir ilişki vardır. Azalan grupta rakamsal olarak azalma olmakla beraber istatistiksel olarak anlamlı değildir

Anahtar sözcükler: Siroz, proBNP, asit

\section{INTRODUCTION}

Brain natriuretic peptide is a cardiac neurohormone secreted from ventricles in response to increased diastolic pressure or volume ${ }^{1}$. Natriuretic Peptide (NP) family consists of Atrial Natriuretic Peptide (ANP), Brain Natriuretic Peptide (BNP), Type C Natriuretic Peptide (CNP), and D type Natriuretic Peptide (DNP) ${ }^{2}$. Many cardiovascular changes including hyperdynamic circulation (normal or decreased arterial blood pressure with increased heart rate, increased cardiac output, and decreased systemic vascular resistance), portal hypertension development, hepatorenal and hepatopulmonary syndromes occur in cirrhosis patients. The hyperdynamic circulation occurring in such cases has not been fully elucidated. Vasomotor tone, decreased vasoconstrictor response, decreased sensitivity to vasoconstrictors, increased levels of existing vasodilators, and the presence of arteriovenous fistulas are some of the conditions thought to be responsible for these $e^{3-4}$. BNP concentrations may be higher when cirrhosis is present. Increased BNP concentrations in people with liver cirrhosis might stem from hyperdynamic state and cirrhotic cardiomyopathy ${ }^{5}$. In this study, pro-BNP levels and ascites levels of patients with cirrhosis at the baseline and control examination after a three-month interval were measured and compared. The purpose of the study was to investigate the relationship between proBNP levels and the amount of ascites in the course of the disease.

\section{MATERIAL AND METHODS}

\section{Study Groups}

This retrospective observational study included 47 cirrhosis patients who had been followed in the Gastroenterology Department of Akdeniz University Faculty of Medicine with varying levels of ascites at the baseline. The patients had been reexamined after 3 months. Patients who were under the age of eighteen, pregnant, previously diagnosed with heart disease or undergone cardiology control during follow-up, patients who had undergone transjugular intrahepatic portosystemic shunt (TIPS), patients with liver disease and related peritonovenous shunt or surgery were excluded from the study. Cardiac examinations of all included patients were normal, no signs of cardiomegaly were present. ECG findings of the patients were normal.

\section{Study Protocol}

The ProBNP measurements of patients with varying levels of ascites at the baseline were made in the morning by collecting $10 \mathrm{ml}$ of blood from the forearm into EDTS tubes. The collected blood was centrifuged at $1500 \mathrm{rpm}$ for 5 minutes, serum was separated and measurement was made. On the same day, ascites measurements were made with a Toshiba SSA-270A brand color doppler USG instrument. Ascites levels in deep regions were measured for all patients. Those up to two centimeters were considered minimal, and those over 6 centimeters massive. 


\section{Statistical Analysis}

The data of the study were analyzed using SPSS 16.0 (Statistical Package For Social Sciences). Variables were expressed with mean values \pm standard deviation. In our study, dependent groups were compared with measurable variables. The parametric Paired Samples T-test was used when the data showed a normal distribution and the nonparametric Wilcoxon paired two-sample test was used when the data was not normally distributed. Statistical significance was accepted as $\mathrm{p}<0.05$.

\section{RESULTS}

The mean age of 47 patients included in the study was $54 \pm 11.2$ years $(\min : 21$, max: 78 , mean 54.47). Of the patients, 31 were male (66\%) and 16 were female (34\%). Nine patients had HBV (19.1\%); 22 patients HCV (46.8\%); 16 patients Cryptogenic liver disease (34.1\%). Most of the patients were on the liver transplant waiting list. According to Child-Pugh classification, 28 patients were Child B (59.6\%); 18 patients Child C (38.3\%); 1 patient Child A (2.1\%). Plasma proBNP levels were found to be significantly increased in patients with ascitic fluid at baseline and control. Values were $137.04 \pm 69 \mathrm{pg} / \mathrm{ml}(\mathrm{p}<0.05)$ in the baseline group and $160.78 \pm 76 \mathrm{pg} / \mathrm{ml}(\mathrm{p}<0.05)$ in the control group. A significant increase was found in plasma proBNP levels in patients in the cirrhosis group with ascites at baseline and in cirrhosis patients with increased ascites fluid and remained constant (Table 1). At baseline, it was found to be $140 \pm 59.3 \mathrm{pg} / \mathrm{ml}$ and at the routine examination 3 months later it was found to be $206.01 \pm 61.91 \mathrm{pg} / \mathrm{ml} .(\mathrm{p}<0.05)$ It was observed that there was a decrease in patients with decreased ascites levels, but this decrease was not statistically significant.

In the diuretic group, the amount of ascites increased in 11 patients, decreased in 19 patients, and remained unchanged in 17 patients. Baseline proBNP level was found to be $140.2 \pm 51 \mathrm{pg} / \mathrm{ml}$ at the baseline in the group with increased ascites, and $206.1 \pm 58 \mathrm{pg} / \mathrm{ml}$ in the control group. $(\mathrm{P}<0.05)$ In the group with increased ascites, proBNP was found to be decreased, however, the change was not statistically significant (Table 2).

When the patients were classified according to the Child score, the proBNP level increased in all three groups, however, this increase was significant only for the Child $\mathrm{C}$ group patients. The baseline proBNP level was $154.27 \pm 67$ in the Child $C$ group and $198.5 \pm 63(\mathrm{p}<0.05)$ in the control group (Table 3).

When the three-month control results of female and male patients were compared, the proBNP level was increased in both groups, nevertheless, statistical significance was obtained only in the female group. The baseline proBNP level was $121.68 \pm 06$ in patient group and $155.1 \pm 80(\mathrm{p}$ $<0.05$ ) in the control group (Table 4).

Table 1: Comparison of baseline plasma BNP levels of cirrhosis patients with increased and unchanged ascites levels.

\begin{tabular}{|l|l|l|}
\hline Variables & $\begin{array}{l}\text { Baseline Plasma proBNP Levels } \\
(\mathrm{pg} / \mathrm{ml}) \\
\text { Mean } \pm \text { S.D. } \\
\mathrm{p}\end{array}$ & $\begin{array}{l}\text { Control Plasma proBNP Levels } \\
(\mathrm{pg} / \mathrm{ml}) \\
\text { Mean } \pm \text { S.D. } \\
\mathrm{p}\end{array}$ \\
\hline $\begin{array}{l}\text { Patients with } \\
\text { increased ascites } \\
\text { level }\end{array}$ & $\begin{array}{l}140.27 \pm 59.13 \\
\mathrm{P}<0.05\end{array}$ & $\begin{array}{l}206.01 \pm 61.91 \\
\mathrm{~N}: 11\end{array}$ \\
\hline $\begin{array}{l}\text { Patients with } \\
\text { unchanged ascites } \\
\text { level }\end{array}$ & $111.7 \pm 47.4$ & \\
$\mathrm{~N}: 17$ & $\mathrm{P}<0.05$ & $148.34 \pm 71.91$ \\
& & $\mathrm{P}<0.05$ \\
\hline
\end{tabular}


Table 2: In the group with increased ascites, proBNP was found to be decreased, however, the change was not statistically significant in patients receiving diuretics.

\begin{tabular}{|l|l|l|}
\hline Parametries & $\begin{array}{l}\text { Patients Receiving Diuretics } \\
\text { with high acid levelN:11 }\end{array}$ & $\begin{array}{l}\text { Patients Receiving Diuretics } \\
\text { with lower acid levelN:18 }\end{array}$ \\
\hline Baseline & $140.2 \pm 51$ & $156.27 \pm 77$ \\
\hline Control & $206.1 \pm 58$ & $143.5 \pm 6$ \\
\hline $\mathrm{p}$ & $<0.05$ & $>0.05$ \\
\hline
\end{tabular}

Table 3: Comparison of Child score and serum proBNP levels.

\begin{tabular}{|l|l|l|}
\hline Variables & Child B & $\begin{array}{l}\text { Child C } \\
\text { N:18 Control }\end{array}$ \\
\hline N:28 & $129.68 \pm 68$ & $154.27 \pm 67$ \\
\hline Control & $240.1 \pm 75$ & $198.5 \pm 63$ \\
\hline$p$ & $<0.05$ & $<0.05$ \\
\hline
\end{tabular}

Table 4: Comparison of plasma pro BNP levels in female and male patients

\begin{tabular}{|l|l|l|}
\hline Variables & $\begin{array}{l}\text { Female } \\
\text { N:16 }\end{array}$ & $\begin{array}{l}\text { Male } \\
\text { N: } 31\end{array}$ \\
\hline Baseline & $121.68 \pm 06$ & $145.29 \pm 67$ \\
\hline Control & $155.1 \pm 80$ & $163.45 \pm 76$ \\
\hline$p$ & $<0.05$ & $>0.05$ \\
\hline
\end{tabular}

\section{DISCUSSION}

Although peptide measurements are very important, circulating pro-BNP concentrations in cirrhosis patients have been evaluated in few studies so far and unfortunately, in the past, there are very few studies showing the daily distribution of plasma BNP levels in patients with preasytic cirrhosis $^{6-7}$. However, it is also known that plasma proBNP concentrations increase in some cirrhosis and preasytic patients compared to controls ${ }^{8}$. Cirrhotic patients have high hyperdynamic background. Kowalsky and Abelmann first described the hyperdynamic state associated with increased cardiac output in 22 patients with cirrhosis in $1953^{9}$. These patients may present with findings similar to heart failure ${ }^{10}$. Our results show that serum proBNP levels are increased in patients with cirrhosis and ascites. BNP concentrations were limitedly related to the severity of cirrhosis according to the Child-Pugh classification and the decompensation component of cirrhosis. We found a relationship between BNP levels and the ChildPugh score, where the Child $\mathrm{C}$ group patients had higher BNP levels than the Child B groups and Child A group. In patients receiving diuretic treatment, pro BNP levels increased with the 
increase in ascites and decreased with a decrease in ascites. Although the increase was significant, the decrease was not. The plasma BNP level in women was higher than in men. It is thought that female sex hormones have a positive effect on BNP gene expression $^{11-12}$. In our study, when the patients were classified into female and male groups, proBNP levels increased in controls for both groups, however, the increase in female patients was significant, while the increase in male patients was not statistically significant. Considering the ratio of female patients to male patients, the number of male patients was high and we thought that this increase in female gender had no effect on the results.

The ProBNP level has also been accepted as an indicator of hepatic elimination in various studies. One study showed that proBNP may be an early indicator of cirrhosis in patients with hepatocellular diseases and be associated with the severity of cirrhosis. According to the results of this study, ascites was found to be associated with collateral circulation, a history of spontaneous bacterial peritonitis, and the presence of esophageal varices and increased BNP levels. These findings suggest that BNP may be a predictive tool for monitoring the clinical progress of patients with cirrhosis. BNP can also be used to monitor responses to the treatment given to these patients. However, further studies are needed to reveal the relationship between BNP and treatment modalities in patients with cirrhosis. In the same study, NT pro-BNP level was found to be significantly correlated with Child scoring and plasma pro-BNP levels were closely related to cirrhosis severity . In our study, proBNP levels increased in patients with increased and unchanged ascites. This increase was significant, however, the rate of decrease was not statistically significant in patients with decreased ascites. Although an increase is expected in patients with increased ascites, an increase in patients with unchanged ascites indicates that the progression of the disease over time is accompanied by an increase in the proBNP level. Furthermore, there was a decrease in proBNP levels in patients with decreased ascites and this change was not significant, indicating that proBNP is particularly associated with progression. In our study, the proBNP level increased in Child C patients. The increases were not significant in Child B and Child A patients. In our study, it has been shown that increased pro-BNP levels are associated with the severity of cirrhosis. Our study results are compatible with the literature. However, it is known that plasma BNP concentrations are increased cirrhotic patients with ascites compared to controls. On the contrary, studies are showing that plasma BNP levels are normal in patients with compensated cirrhosis ${ }^{6-7}$.

ProBNP concentration decreases in studies using diuretics. Central hypervolemia decreases as a result of regular salt-restricted diet ( $2 \mathrm{~g} /$ day) and diuretic (spiranolactone $200 \mathrm{mg} /$ day and furosemide $80 \mathrm{mg} /$ day) given in acid-forming cirrhosis patients, which leads to a decrease in the amount of acid fluid in cirrhosis patients. As a result of this, it shows that the reduction or normalization of plasma pro-BNP levels can be a guiding marker of pro-BNP in treatment ${ }^{1}$. These drugs include angiotensin converting enzyme inhibitors and diuretics. These drugs will impair hypervolemia and suppress the hyperdynamic system in cirrhosis patients. The ProBNP levels decreased in patients with decreased ascites after treatment, however the change was not significant. The present study has some limitations. The small sample size is one of the limitations. Studies on this issue need to be conducted in larger patient groups and in a multi-centered manner.

\section{REFERENCES}

1. De Lemos JA, Mc Guire DK, Drazner MH. Btype natriuretic peptide in cardiovascular disease. Lancet. 2003; 362: 316-22. doi: 10.1016/S0140-6736(03)13976-1

2. Moller S, Bendtsen F, Henriksen JH. Effect of volume expansion on systemic hemodynamics and central and arterial blood volume in cirrhosis. Gastroenterology 1995; 109:1917-25

3. $\mathrm{Yu} \quad \mathrm{CM}, \quad$ Sanderson JE. Plasmabrainnatriureticpeptide- an independentpredictor of cardiovascularmortality in acuteheartfailure. Eur J Heart Fail 1999;1:59-65.

4. Groszmann RJ. Vasodilatation and hyperdynamic circulatory state in chronic liver disease. In: Bosch J, Groszmann RJ, editors. Portal hypertension. Pathophysiology and treatment. Oxford: Blackwell 1994: 17-26.

5. Pimenta, J, Paulo C, Gomes A, Silva S, RochaGonçalves F, Bettencourt P. B-type natriuretic peptide is related to cardiac function and prognosis in hospitalized patients with decompnesated cirrhosis. Liver International. 2010; 30: 1059-66. doi:10.1111/j.14783231.2010.02266.x, PMID: 20492497.

6. Henriksen JH, Gøtze JP, Fuglsang $\mathrm{S}$ et al. Increasedcirculatingpro- brainnatriureticpeptide (proBNP) andbrainnatriureticpeptide (BNP) in patientswithcirrhosis: 
relationtocardiovasculardysfunctionandseverity of disease. Gut 2003;52:1511-17.

7. Arroyo V, Ginès $\mathrm{P}$, Gerbes AL, et al. Definition and diagnostic criteria of refractory ascites and hepatorenal syndrome in cirrhosis. Hepatology 1996; 23:164-76.

8. Berger R, Huelsman M, Strecker K, et al. Btype natriuretic peptide predicts sudden death in patients with chronic heart failure. Circulation. 2002; 105:2392-2397.

9. Kowalski HJ, Abelman WH. The cardiac output at rest in Laennecs Cirrhosis. J Clin Invest 1953; 32:1025-33.
10.Møller S, Henriksen JH. Circulatoryabnormalities in cirrhosiswithfocus on neurohumoralaspects. Semin Nephrol 1997;17:505-19.

11.McCullough PA, Omland T, Maisel AS. Btypenatriureticpeptides:

diagnosticbreakthroughforclinicians.

RevCardiovascMed 2003;4:72-80.

12. Clerico A, Del Ry S, Maffei S, Prontera C, Emdin M, Giannessie D. The circulating levels of cardiac natriuretic peptide hormones in healty adults; effects of age and sex. Clin Chem Lab Med 2002; 40: 371-7. 